\title{
Aleksandra Kil
}

Uniwersytet Wrocławski

\section{O fiszkach Stanisława Pietraszki. Komentarz do Archiwum*}

Otwierając dział archiwalny w niniejszym numerze, zaglądamy jednocześnie do prywatnego archiwum uczonego, czyli dotychczas niepublikowanej kartoteki profesora Stanisława Pietraszki, pomysłodawcy i pierwszego redaktora „Prac Kulturoznawczych”. Zaprezentowane tu fiszki zostały wybrane z obszernego zbioru odręcznych notatek, stanowiącego część spuścizny po Profesorze zdeponowanej w Bibliotece Instytutu Kulturoznawstwa i Muzykologii UWr. Zapiski robione były na kartkach (zwykle formatu A6 oraz o orientacji poziomej) i umieszczane w kopertach (łącznie 954), opatrzonych hasłami przedmiotowymi (lub, rzadziej, skrótami alfanumerycznymi). Koperty znajdują się w czterech pudełkach: dwóch bibliotecznych pudłach katalogowych i dwóch pudełkach po butach. Można przypuszczać, że pierwotny układ kopert miał być zgodny z kolejnością alfabetyczną (do dzisiaj nie w pełni zachowaną). Fiszki zawierające notatki własne, wyimki i opracowania lektur, a czasem nawet same adresy bibliograficzne opracowywane były od lat pięćdziesiątych aż do końca aktywności akademickiej Pietraszki (najświeższą datą, na jaką można trafić, jest październik roku akademickiego 2007/2008).

Reprodukowane w tym numerze karty poświęcone tematyce religii i sacrum pochodzą z brązowego pudełka bibliotecznego, które liczy najwięcej kopert i zawiera fiszki o tematyce kulturoznawczej (w odróżnieniu od tych starszych, pochodzących jeszcze z okresu pracy polonistycznej Pietraszki). Wpisaną w kwadracik literę „K” umieszczoną w lewym górnym rogu na kopercie można odczytywać właśnie jako identyfikację związku danego zagadnienia z nowym, rozwijanym przez Pietraszkę od lat sześćdziesiątych zainteresowaniem problematyką kultury i studiów kulturoznawczych. Widoczna na jednej z fiszek litera „W” to z kolei oznaczenie sugerujące, że kartka mogła być używana przez profesora podczas wykładów (o tych słynnych małych karteczkach przynoszonych na zajęcia wspominają jego dawni uczniowie).

${ }^{*}$ Tekst Aleksandry Kil otwiera cykl prezentacji fiszek prof. Stanisława Pietraszki z jego prywatnego archiwum (przyp. red.). 
Ze względu na tematykę przedstawionych fiszek i całego tomu warto wspomnieć o rodowodzie nowoczesnej kartoteki i kart katalogowych — ten wiąże się bowiem z sekularyzacją dóbr kościelnych, która działa się w XVIII w. w cesarstwie habsburskim oraz we Francji. Według Markusa Krajewskiego, autora książki Zettelwirtschaft. Die Geburt der Kartei aus dem Geiste der Bibliothek ${ }^{1}$, pracę nad pierwszym bibliotecznym katalogiem kartkowym rozpoczął w Wiedniu w $1780 \mathrm{r}$. Gottfried van Swieten, prefekt cesarskiej biblioteki i polityk w służbie Marii Teresy, a potem jej syna Józefa II. Stworzenie efektywnego katalogu kartkowego miało być odpowiedzią na przyrastającą lawinowo liczbę książek, głównie tych, które trafiały do Wiednia z zamykanych klasztorów, przejmowanych przez aparat państwowy w ramach działań zwanych też reformami józefińskimi. Podobną inicjatywę (choć mniej trwałą) podjęto też w tużporewolucyjnej Francji, kiedy to chciano zinwentaryzować księgozbiory odebrane głównie Kościołowi i w trosce o jednolitą formę spisu (standaryzacja była kluczem do sukcesu katalogu) wykorzystano do tego talie kart do gry, adaptując zresztą wcześniejszy (1775 r.) pomysł francuskiego duchownego François Roziera.

$* * *$

W duchu archeologii mediów papierowe fiszki uczonego nazywa się czasem bazą danych (avant la lettre). Zdaje się, że użycie takiej formuły służy podkreśleniu, że fiszkom bliżej do cyfrowych form gromadzących informacje, zorientowanych nie tyle na obiekty, ile raczej na proces; operacje dokonywane na zbiorze i konstytuowane przez relacje między swymi częściami. Można też uznać — za Ernstem van Alphenem - że baza danych to po prostu współczesna wersja metafory archiwum ${ }^{2}$, która w wypadku fiszek narzuca się w dość oczywisty sposób. Zgodnie z klasyczną już propozycją Lva Manovicha z jego Języka nowych mediów bazę danych można rozpatrywać jako formę symboliczną konkurencyjną względem narracji. Ich relację Manovich opisuje też, posiłkując się żargonem strukturalistycznym: w rzeczywistości precyfrowej narracja jest syntagmą, baza danych paradygmatem. Status bazy danych (w przeciwieństwie do urzeczywistnionej kombinacji elementów, czyli syntagmy) oznacza więc także istnienie w sposób wirtualny, potencjalny, a nawet nierozpoznany i pomijany. Przedsięwzięta tu publikacja fiszek (w zamyśle Redakcji kontynuowana także w kolejnych tomach) nawet tylko wybranych, nie w postaci całościowej cyfrowej bazy danych — jest zatem w pewnym sensie eksplorowaniem paradygmatycznego wymiaru dzieła Pietraszki. Nie tylko odsłania warsztat badacza, skłania do śledzenia historii pewnych pomysłów, lecz może także zachęcać do poszukiwania „miejsc pustych”.

\footnotetext{
${ }^{1}$ Korzystam z anglojęzycznego wydania tej pracy: M. Krajewski, Paper Machines. About Cards and Catalogs, 1548-1929, przeł. P. Krapp, Cambridge, MA 2011, s. 32-47.

${ }^{2}$ Por. E. van Alphen, Staging the Archive. Art and Photography in the Age of New Media, London 2014, s. 10-12.
} 


\section{囚 RELIGIA}

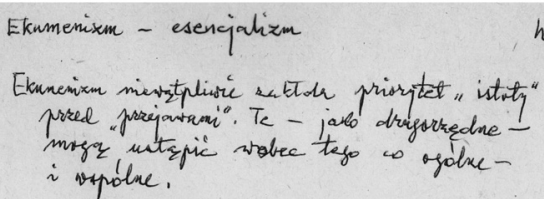

REL

Prace Kulturoznawcze 21, 2017, nr 1

(C) for this edition by CNS
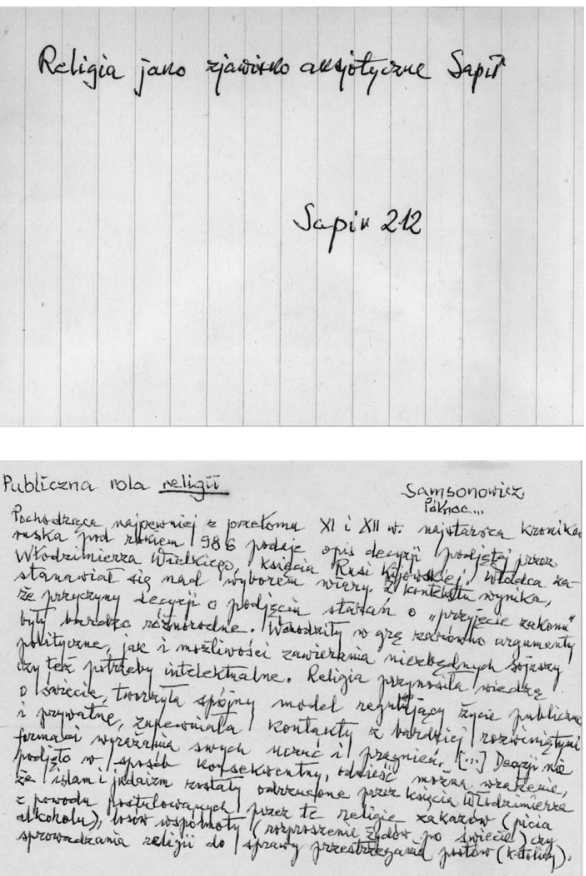